\title{
ANALISIS RUNGGU RAKUT SITELU SUKU KARO SEBAGAI STRATEGI UNTUK MENINGKATKAN KEMAMPUAN BERBICARA MAHASISWA PROGRAM STUDI PENDIDIKAN BAHASA INGGRIS UNIVERSITAS PRIMA
}

\author{
oleh:
}

\section{Yenita Sembiring (yenitasembiring@unprimdn.ac.id)}

\begin{abstract}
ABSTRAK-Analisis Runggu Rakut Sitelu Suku Karo Sebagai Strategi Untuk Meningkatkan Kemampuan Berbicara Mahasiswa Program Studi Pendidikan Bahasa Inggris Universitas Prima Indonesia adalah suatu penelitian yang berfokus kepada penggunaan budaya Karo Runggu Rakut Sitelu sebagai satu strategi mengajar yang dapat digunakan oleh dosen dalam proses pembelajaran. Runggu Rakut Sitelu adalah sistem komunikasi dalam kekerabatan suku Karo yangmelibatkan tiga komponen, yaitu kalimbubu, senina dan anak beru (Rakut Sitelu).
\end{abstract}

Kata Kunci: Runggu Rakut Sitelu, Berbicara

\section{A. PENDAHULUAN}

Penguasaan bahasa Inggris pada sekarang ini memiliki peran yang penting. Oleh karena itu pendidikan di Indonesia mewajibkan Bahasa Inggris menjadi salah satu materi pembelajaran dari tingkat Sekolah dasar sampai kepada Pendidikan tingkat tinggi.Pembelajaran bahasa Inggris memiliki tujuan agar peserta didik mampu menguasai dan berkomunikasi menggunakan bahasa. Namun, penguasaan bahasa Inggris bukanlah hal yang mudah bagi peserta didik. Banyak tantangan yang dihadapi oleh peserta didik dalam menguasai bahasa Inggris. Hal ini disebabkan oleh beberapa hal yaitu (1) para peserta didik enggan menggunakan bahasa Inggris dan (2) Para peserta didik kurang menguasai bahasa tersebut (Oradee, 2012).

Berbicara merupakan keterampilan yang paling penting dalam penguasaan bahasa asing (Tahir, 2015). Namun, banyak peserta didik mengalami kesulitan dalam berbicara Hal ini disebabkan karena Berbicara juga merupakan keterampilan yang paling sulit dikuasai oleh peserta didik dibandingkan keterampilan yang lain dalam pembelajaran bahasa Asing (Gudu, 2015). Hal juga dihadapi oleh mahasiswa program studi Pendidikan Bahasa Inggris di Universitas Prima Indonesia. Banyak dari mereka yang tidak menguasai bahasa Inggris khususnya dalam keterampilan berbicara, walaupun mereka mendapat pembelajaran Speaking selama empat semester. Hal ini bukan asumsi peneliti saja. Kondisi tersebut diketahui peneliti dari beberapa sumber yaitu dosen yang mengajar di kelas, (2) Guru dan kepala sekolah dimana para mahasiswa melakukan PPL dan (3) pengguna lulusan. Hal tersebut juga dapat dilihat dari presentasi nilai matakuliah Berbicara mahasiswa yang dikategorikan baik $15 \%$, cukup $40 \%, 22 \%$ kurang dan $23 \%$ buruk. Hal inilah yang membuat peneliti merasa bahwa penting dilakukan penelitian mengenai hal tersebut. 
Untuk memperkuat alasan untuk melakukan penelitian ini, maka peneliti mengutip penelitian yang relevan. Darmayenti \& Nofiadri (2015) melakukan penelitian dengan judul Mingle Model for Teaching English Speaking Skills for College Students. Penelitian tersebut mengkaji penggunaan model belajar Mingel terhadap kemampuan berbicara mahasiswa di Universitas Imam Bonjol Padang. Dari hasil olah data ditemukan bahwa penggunaan model Mingel berpengaruh terhadap kemampuan berbicara mahasiswa. Peranginangin dan Perbawaningsih dengan judul penelitian Implementasi Tradisi Ertutur Suku Batak Karo Sebagai Model Komunikasi Interpersonal Mahasiswa Perantau di Yogyakarta. Dari penelitian diketahui bahwa dengan menerapkan ertuturdapat menumbuhkan sikap keterbukaan antar mahasiswa.

Berdasarkan penjelasan diatas, maka peneliti hendak menganalisis sistem komunikasi Karo sebagai strategi untuk meningkatkan kemampuan berbicara mahasiswa pendidikan bahasa Inggris. Sistem tersebut dinamakan Runggu Rakut Sitelu. Alasan pemilihan sistem tersebut adalah sistem tersebut merupakan satuhal yang baru bagi para mahasiswa sehingga peneliti beranggapan dengan mengetahui hal yang baru mereka akan merasa lebih termotivasi untuk belajar. Melalui penerapan sistem komunikasi ini dalam pembelajaran Berbicara dapat memberikan kontribusi positif terhadap mahasiswa untuk meningkatkan kemampuan berbicara mahasiswa dan akhirnya lulusan prodi Bahasa Inggris Universitas Prima Indonesia menjadi mahasiswa yang unggul dalam menggunakan bahasa Inggris. Masalah penelitian ini adalah: 1) Bagaimana menganalisis sistem komunikasi Runggu Rakut Sitelu suku Karo? 2) Bagaimana upaya menjadikan sistem komunikasi Runggu Rakut Sitelu menjadi strategi belajar kelas berbicara pada prodi Pendidikan Bahasa Inggris? Tujuan penelitian ini adalah: 1) untuk menganalisis sistem komunikasi Runggu Rakut Sitelu suku Karo. 2) Untuk menjadikan sistem komunikasi Runggu Rakut Sitelu menjadi strategi belajar pada prodi Pendidikan Bahasa Inggris.

\section{B. METODE PENELITIAN}

Desain penelitian ini adalah diskriptif kualitatif. Deskriptif kualitatif menurut Ary (2010:160)adalah desain penelitian dimana tidak ada perlakuan terhadap subjek penelitian. Desain penelitian ini hanya bersifat mendiskripsikan apa yg terjadi pada satu fenomena. Setiap penelitian haruslah memiliki instrument. Intrument penelitian menurut Frankael \& Wallen (2009:117) adalah alat yang digunakan untuk mengumpulkan data dalam sebuah penelitian. Ada banyak jenis-jenis intrumen penelitian. Dalam penelitian ini, peneliti akan menggunakan instrumen wawancara untuk mengumpulkan data. Data dalam penelitian ini adalah data lisan berupa hasil wawancara dengan informan mengenai bentuk sistem komunikasi Runggu Rakut Sitelu suku karo. Data diperoleh dari hasil wawancara dengan informan yang berada di tiga lokasi asal suku Karo, yaitu Tanah Karo (Karo Gugung), Langkat ( Karo Langkat) dan Deli Serdang ( Karo Jahe). Lokasi penelitian ini di lkukan di tiga tempat. Hal ini dikarenakan asal suku karo yang berasal dari tiga lokas yang berbeda. Tiga lokasi itu 
adalah Tanah Karo (Karo Gugung), Langkat ( Karo Langkat) dan Deli Serdang ( Karo Jahe). Penelitian ini akan berlangsung selama dua belas bulan. Penelitian ini akan dimulai bulan Juni 2018 sampai bulan Juni 2019. Data yang sudah dikumpulkan akan dianalisis. Teknik yang digunakan untuk menganalisis data adalah teknik triangulasi menurut Miles dan Huberman (2007:1620).Data akan dianalisis berdasarkan tiga tahapan, yaitu: tahapan reduksi data, tahapan penyajian data dan tahapan penarikan kesimpulan.

\section{HASIL PENELITIN}

Data dari penelitian ini adalah hasil wawancara dan observasi lapangan. Data diambil dari tiga wilayah yang berbeda, yaitu dari kabupaten Tanah Karo,Kabupaten Deli Serdang dan kabupaten Langkat. Data yang diperoleh dari hasil wawancara dengan informan dari tiga wilayah yang berbeda, yaitu dari kabupaten Tanah Karo, Kabupaten Deli Serdang dan kabupaten Langkat di olah untuk menghasilkan satu kesimpulan.

Runggu sebagaimana dikatakan sebelumnya adalah model sistem komunikasi dalam bermusyawarah untuk mengambil satu keputusan. Didalam Runggu yang terlibat adalah Rakut Sitelu. Rakut Sitelu didefinisikan sebagai tiga periuk (Prist, 2002). Rakut Sitelu terdiri dari tiga unsur sebagai berikut (Tarigan, 2008): (1) Senina, (2) Anak Beru, (3) Kalimbubu. Runggu dilakukan setiap ada pesta adat, baik dalam suka (perkawinan, masuk rumah baru,dll dan duka (kematian). Namun dalam hal ini, peneliti hanya akan menerapkan model sistem komunikasi Runggu dalam acara pesta adat pernikahan. Pada pesta perkawinan runggu dilakukan oleh kedua belah pihak yaitu pihak mempelai wanita dan pria. Kedua belah pihak akan melakukan dialog sebagaimana berdasarkan urutan berikut: 1 . anak beru pihak mempelai wanita akan bertanya kepada anak beru pihak mempelai pria, 2) anak beru pihak mempelai pria akan bertanya kepada senina kalimbubu pihak mempelai pria. 3) senina kalimbubu pihak mempelai pria bertanya kepada pihak kalimbubu pihak mempelai pria, 4) kalimbubu pihak mempelai pria memberi tanggapan kepada senina pihak mempelai pria, 5) tanggapan kalimbubu pihak mempelai pria disampaikan senina pihak mempelai pria kepada anak beru pihak mempelai pria, 6) anak beru pihak mempelai pria menyampaikan tanggapan senina kalimbubu pihak mempelai pria kepada anak beru pihak mempelai wanita, 7) anak beru pihak mempelai wanita bertanya kepada senina pihak mempelai wanita mengenai tanggapan dari pihak mempelai pria, 8) senina pihak mempelai wanita bertanya mengenai tanggapan tersebut kepada kalimbubu pihak mempelai wanita, 9) kalimbubu pihak mempelai wanita memberi tanggapan kepada senina pihak mempelai wanita, 10) senina pihak mempelai wanita menyampaikan tanggapan kepada anak beru pihak mempelai wanita, 11) anak beru pihak mempelai wanita menyampaikan tanggapan kepada anak beru pihak mempelai pria.

\section{KESIMPULAN}

Berdasarkan analisis data, maka peneliti menyimpulkan bahwa:

1. Runggu diartikan sebagai pengambilan keputusan melalui tahapan musyawarah untuk mufakat. Pada suku Karo, runggu dilaksanakan pada acara peradatan perkawinan. Proses runggu pada adat 
pekawinan suku Karo diawali pada acara pertunangan (Ngembah belo selambar) yang kemudian akan diteruskan pada acara peradatan pesta perkawinan.

2. Tahapan dari runggu pada suku Karo pada adat pesta perkawinan dibagi menjadi dua bagian, yaitu Runggu sewaktu acara lamaran dan Runggu sewaktu pesta adat perkawinan.

a. Runggu pada acara lamaran (Ngembah Belo Selambar)

Acara lamaran dilaksanakan untuk mengetahui kesediaan calon mempelai, siapa orang tuanya dan kerabatnya. Acara diawali dengan makan bersama dan diteruskan dengan proses runggu.

Pihak-pihak yang terlibat dalam acara tersebut adalah pihak mempelai wanita dan pihak mempelai pria, yang dijelaskan lebih terperinci sebagai berikut:

1. Pihak mempelai wanita terdiri dari:
a. Sukut (yang mengadakan pesta/orang tua dari mempelai wanita beserta keluarga)
b. Sembuyak dan Senina (pihak satu marga dengan sukut)
c. Anak beru (adik/kakak perempuan dari orangtua lakilaki mempelai wanita).

2. Pihak mempelai pria terdiri dari:
a. Sukut (yang mengadakan pesta/orang tua dari mempelai pria beserta keluarga)
b. Sembuyak dan Senina (pihak satu marga dengan sukut)
c. Anak beru (adik/kakak perempuan dari orangtua laki-laki mempelai pria).

b. Runggu pada Pesta Adat Perkawinan Runggu pada tingkatan lamaran akan dilanjutkan pada tingkatan pesta adat perkawinan. Pada tingkat tersebut maka runggu akan dilakukan oleh rakut sitelu yaitu terdiri dari Senina, Kalimbubu dan Anak beru.

Runggu dilakukan oleh pihak mempelai wanita dan pihak mempelai pria. Adapun komposisinya adalah:

1. Pihak mempelai wanita terdiri dari:

a. Senina adalah kerabat yang satu marga dengan orang tua pihak mempelai wanita.

b. Kalimbubu adalah saudara laki-laki dari ibu mempelai wanita.

c. Anak beru adalah saudara perempuan dari ayah mempelai wanita.

2. Pihak mempelai pria terdiri dari:

a. Senina adalah kerabat yang satu marga dengan orang tua pihak mempelai pria.

b. Kalimbubu adalah saudara laki-laki dari ibu mempelai pria.

c. Anak beru adalah saudara perempuan dari ayah mempelai pria.

Pada proses Runggu Rakut Sitelu (Senina, Kalimbubu dan Anak beru) ada alur percakapan yang dilaksanakan yaitu:

1. Anak beru pihak mempelai pria aan bertanya kepada anak beru pihak mempelai wanita. Yang ditanyakan misalnya mengenai persiapan pesta dan tamu undangan.

2. Anak beru pihak mempelai wanita tidak akan langsung menjawab 
pertanyaan tersebut, tetapi mereka akan bertanya kepada pihak Senina dari mempelai wanita.

3. Setelah mendapat pertanyaan dari Anak beru, maka pihak senina tidak langsung memberi jawaban tetapi dia akan berdikusi dengan pihak kalimbubu.

4. Setelah mendapat jawaban maka Senina akan menyampaikan kepada Anak beru.

5. Anak beru pihak mempelai wanita pun akan menyampaikan jawaban tersebut kepada pihak anak beru mempelai pria.

6. Anak beru pihak mempelai pria akan menyampaikan informasi kepada Senina dan Kalimbubu.

\section{DAFTAR PUSTAKA}

Oradee, Thanyalak. 2012. Developing Speaking Skills Using Three Communicative Activities (Discussion, Problem-Solving and Role Playing). International Journal of Social Science and Humanity Vol.2 No.6. Hal:8.

Tahir, Saidna Zulfiqar A. 2015. Improving Speaking Skills Through Yahoo Massanger at University of Iqra Buru. International Journal of Language and Linguistics 3 (3). Hal:176.

Gudu, Benter Oseno. 2015. Teaching Speaking Skills in English language
Using Classroom Activities. Journal of Education and Practice Vo.6 No.35. Hal:56.

Darmayenti \& Nofiadri. 2015. Mingle Model For Teaching English Speaking Skill For college Students. Vol. 22, No.1,Februari 2015. Hal 1-9.

Harmer, Jeremy. 2001. How to Teach English. Longman Pearson: Cambridge. London.

Derakhshan et al. 2016. Developing EFL Learners' Speaking Ability, Accuracy and Fluency. English language and Literature Studies Vol.6 No.2. Hal:178

Prinst, Darwin. 2002. Kamus KaroIndonesia. Medan: Penerbit Bina Media. Tarigan, Sarjani Drs. 2008. Dinamika Orang Karo, Budaya dan Modernisme. Medan: Lamerose Press.

Ary, et all. 2010. Introduction to Research in Education. Wadsworth. Belmonth. USA. Dawson, Cathereine. 2002. Practical Research method. How to books, ltd. London. Miles, Mathew B dan A,. Michael Huberman. 2007. Analisis data kualitatif. Buku Sumber Tentang Metode-metode Baru. Jakarta. UI Press. 